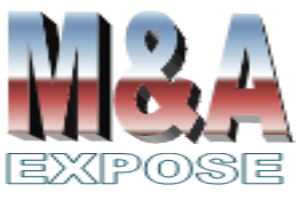

http://jurnal.usahid.ac.id/index .php/accounting
${ }^{1}$ Magister Akuntansi

Universitas Trisakti

1umailahvinka@amail.com

\section{Pengaruh Thin Capitalization dan Konservatisme Akuntansi terhadap Tax Avoidance dengan Kepemilikan Institusional sebagai Variabel Moderasi}

\author{
Vinka Jumailah ${ }^{1}$
}

\begin{abstract}
Abstrak
Tujuan penelitian ini adalah menguji hubungan antara thin capitalization dan konservatisme akuntansi terhadap tax avoidance dengan kepemilikan institusional sebagai variable pemoderasi. Populasi yang digunakan dalam penelitian ini adalah perusahaan consumer goods yang terdaftar di Bursa Efek Indonesia pada tahun 2014-2018. Pengambilan sampel dilakukan dengan metode purposive sampling. Teknik pengujian data dalam penelitian ini dengan menggunakan analisis regresi linear berganda. Hasil penelitian membuktikan bahwa thin capitalization berpengaruh positif terhadap tax avoidance, konservatisme tidak berpengaruh terhadap tax avoidance, kepemilikan institusional dapat memperlemah pengaruh thin capitalization terhadap tax avoidance, dan kepemilikan institusional tidak dapat memoderasi pengaruh konservatisme akuntansi terhadap tax avoidance.
\end{abstract}

Kata kunci : Kepemilikan Institusional, Konservatisme Akuntansi, Tax Avoidance, Thin Capitalization.

\section{Abstract}

The purpose of this study is to examine the relationship between thin capitalization and accounting conservatism on tax avoidance with institutional ownership as a moderating variable. The population used in this study is consumer goods companies listed on the Indonesia Stock Exchange in 2014-2018. Sampling was done by purposive sampling method. The data testing technique in this study is to use multiple linear regression analysis. The results prove that thin capitalization has a positive effect on tax avoidance, conservatism has no effect on tax avoidance, institutional ownership can weaken the effect of thin capitalization on tax avoidance, and institutional ownership cannot moderate the effect of accounting conservatism on tax avoidance.

Keywords: Institutional Ownership, Accounting Conservatism, Tax Avoidance, Thin Capitalization. 


\section{PENDAHULUAN}

Pajak merupakan kontribusi wajib yang diberikan wajib pajak kepada negara, namun negara tidak memberikan imbalan langsung terhadap wajib pajak tersebut. Pajak bersifat memaksa, karena merupakan kontribusi wajib. Pajak digunakan untuk keperluan negara bagi sebesar-besarnya kemakmuran rakyat. Perpajakan di Indonesia diatur melalui pasal 23A UUD 1945 dan peraturan lainnya seperti Undang-Undang No. 28 Tahun 2007 tentang Ketentuan Umum dan Tata Cara Perpajakan (Online Pajak, 2018). Berdasarkan laporan bertajuk Economic Opennes: Indonesia Case Study yang diterbitkan pada 9 Oktober 2019 oleh Legatum Institute (LI) menyebutkan bahwa pembayaran pajak di Indonesia menjadi yang paling memberatkan di ASEAN. Rata-rata pembayaran pajak pelaku usaha di Indonesia selama setahun mencapai 43 kali, sedangkan di negara ASEAN lainnya seperti Singapura rata-rata pembayaran pajaknya 5 kali per tahun, Laos 35 kali, Vietnam 10 kali, Filipina 14 kali, Thailand 21 kali, Myanmar 31 kali, Malaysia 8 kali, dan Kamboja 40 kali. Rata-rata pembayaran pajak tersebut dihitung dari jumlah total pajak yang dibayar, metode pembayaran, jumlah frekuensi pembayaran, hingga frekuensi pengarsipan. Ini juga termasuk pajak yang dipotong perusahaan seperti pajak penjualan, PPN, dan pajak karyawan. Pembayaran pajak masih dianggap memberatkan, sehingga perusahaan seringkali melakukan penghindaran pajak.

Salah satu cara perusahaan melakukan penghindaran pajak yaitu melalui thin capitalization, di mana keputusan investasi perusahaan dalam mendanai operasional perusahaan adalah dengan cara pendanaan utang daripada modal ekuitas dalam struktur modalnya, karena utang dapat meningkatkan nilai perusahaan dengan adanya insentif pajak berupa beban bunga pinjaman (Olivia, 2019). Faktor lain yang dapat mempengaruhi tax avoidance adalah konservatisme akuntansi. Menurut Susanti dalam Sjahputra (2019), konservatisme akuntansi merupakan kecenderungan yang dimiliki oleh seorang akuntan maupun manager yang mensyaratkan tingkat tinjauan yang lebih detail dan lebih cermat untuk mengakui laba (good news in earnings) dibanding mengakui rugi (bad news in earnings). Tingkat konservatisme akuntansi dalam pelaporan keuangan perusahaan ditentukan oleh faktor komitmen pihak internal perusahaan dalam menginformasikan laporan keuangan yang transparan, akurat, dan tidak menyesatkan. Hal ini tercermin dari good corporate governance. Apabila suatu perusahaan memiliki suatu mekanisme corporate governance yang terstruktur dengan baik maka akan berbanding lurus dengan kepatuhan dalam memenuhi kewajiban perpajakannya.

Penelitian Olivia (2019) menunjukkan bahwa thin capitalization tidak berpengaruh terhadap penghindaran pajak, profitabilitas berpengaruh positif terhadap penghindaran pajak, kepemilikan institusional tidak dapat memoderasi pengaruh thin capitalization terhadap penghindaran pajak dan kepemilikan institusional dapat memperlemah pengaruh positif profitabilitas terhadap penghindaran pajak. Sedangkan penelitian Sjahputra (2019) menunjukkan bahwa konservatisme akuntansi dan inventory intensity berpengaruh negatif terhadap penghindaran pajak.

Perbedaan penelitian ini dengan penelitian sebelumnya terletak pada variabel penelitian, tahun penelitian, dan pengukuran. Penelitian ini menggunakan variabel gabungan dari penelitian terdahulu yang terdiri dari thin capitalization dan konservatisme akuntansi sebagai variabel independen, tax avoidance sebagai variabel dependen, dan kepemilikan institusional sebagai variabel moderasi. 
Berdasarkan latar belakang diatas, maka rumusan masalah penelitian ini yaitu 1) Apakah thin capitalization berpengaruh terhadap tax avoidance? 2) Apakah konservatisme akuntansi berpengaruh terhadap tax avoidance? 3) Apakah kepemilikan institusional memoderasi pengaruh thin capitalization terhadap tax avoidance? 4) Apakah kepemilikan institusional memoderasi pengaruh konservatisme akuntansi terhadap tax avoidance?

\section{TINJAUAN PUSTAKA}

Teori agensi merupakan teori yang menjelaskan tentang hubungan kontraktual antara pihak yang menentukan pengambilan keputusan (pemegang saham) dengan pihak yang menjalankan keputusan tersebut (agent). Agent dipercaya untuk mengelola atau menjalankan manajemen perusahaan karena dianggap sebagai tenaga-tenaga profesional yang lebih berpengalaman dalam menjalankan bisnis serta dapat mewujudkan tujuan perusahaan yaitu agar pemilik perusahaan memperoleh keuntungan yang semaksimal mungkin dengan biaya yang seefisien mungkin (Khairandy, 2007: 16-17).

Freeman mempopulerkan pemangku kepentingan dan mendefinisikannya sebagai "kelompok atau individu yang dapat mempengaruhi atau dipengaruhi oleh pencapaian tujuan organisasi". Tujuan teori Stakeholder adalah untuk membantu perusahaan memperkuat hubungan dengan kelompok-kelompok eksternal untuk mengembangkan keunggulan kompetitif. Hubungan yang kuat dengan para pemangku kepentingan adalah berdasarkan kepercayaan, rasa hormat, dan kerja sama (Khairandy, 2007). Definisi ini menjelaskan bahwa perusahaan harus lebih memperhatikan stakeholder yang merupakan pihak yang baik secara langsung maupun tidak langsung mempengaruhi dan dipengaruhi aktivitas dan kebijakan yang diambil perusahaan. Jika perusahaan tidak memperhatikan stakeholder, maka memungkinkan terjadinya perselisihan antara perusahaan dengan stakeholder.

Menurut Mardiasmo (2003), penghindaran pajak (Tax Avoidance) adalah salah satu usaha meringankan beban pajak dengan tidak melanggar undang-undang yang ada. Adapun cara perusahaan melakukan penghindaran pajak menurut Merks (2007) dalam Kurniasih \& Sari (2013) adalah sebagai berikut: 1) Memindahkan subjek pajak dan atau objek pajak ke negara-negara yang memberikan perlakuan pajak khusus atau keringanan pajak atas suatu jenis penghasilan, 2) Usaha penghindaran pajak dengan mempertahankan substansi ekonomi dari transaksi melalui pemilihan formal yang memberikan beban pajak yang paling rendah, 3) Ketentuan anti avoidance atas transaksi transfer pricing, thin capitalization, treaty shopping, controlled foreign corporation serta transaksi yang tidak mempunyai substansi ekonomi.

Thin capitalization merujuk pada keputusan investasi oleh perusahaan dalam mendanai operasi bisnis dengan mengutamakan pendanaan utang dibandingkan menggunakan ekuitas dalam struktur modalnya (Taylor \& Richardson, 2013). Thin capitalization dapat menjadi masalah dalam perpajakan dikarenakan adanya perbedaan perlakuan antara investasi modal dan investasi utang. Pada investasi modal, pengembalian modal dalam bentuk dividen akan dikenakan pajak, sedangkan melalui pendanaan utang akan menimbulkan beban bunga yang dapat dijadikan sebagai pengurang penghasilan kena pajak.

Menurut FASB Statement of Concept No.2, konservatisme adalah reaksi hati hati untuk menghadapi ketidakpastian dan risiko terhadap situasi bisnis telah dipertimbangkan di 
masa yang akan datang. Defenisi konservatisme yang lebih deskriptif adalah memilih prinsip akuntansi yang mengarah pada minimalisasi laba kumulatif yang dilaporkan yaitu mengakui pendapatan lebih lambat, mengakui biaya lebih cepat, menilai aset dengan nilai terendah, dan menilai kewajiban dengan nilai yang lebih tinggi (Sarra, 2017).

Kepemilikan Institusional adalah kondisi yang menunjukkan bahwa institusi luar negeri, institusi keuangan, institusi berbadan hukum, dana perwalian, pemerintah, dan institusi lainnya memiliki saham perusahaan. Teori Stakeholder menjelaskan bahwa tiap pemangku kepentingan turut menentukan kinerja perusahaan, termasuk kinerja sosialnya. Institusi dianggap sebagai pihak yang dapat mengawasi dan mengelola investasinya dengan baik dari segi pengetahuan, sistem informasi, maupun sumber daya yang dimiliki. Machmud dan Djakman (2008) dalam Krisna (2016) menyatakan kepemilikan institusional yang tinggi akan menimbulkan usaha pengawasan yang lebih besar oleh pihak investor sehingga dapat menghalangi perilaku opportunistik manajer.

Thin Capitalization mengutamakan pendanaan utang dalam struktur modalnya, yang dapat menimbulkan insentif pajak berupa beban bunga yang dapat diperlakukan sebagai pengurang penghasilan kena pajak. Sedangkan pada investasi modal, pengembalian modal dalam bentuk dividen akan dikenakan pajak. Perbedaan perlakuan bunga dan dividen ini, dapat menjadi celah bagi strategi penghindaran pajak (Olivia, 2019). Semakin tinggi thin capitalization maka semakin tinggi beban bunga yang harus dibayar yang tentunya akan menggerus laba perusahaan dan pada akhirnya mengecilkan pajak penghasilan terutang. Hasil penelitian Khomsatun (2012) dan Andawiyah (2019) menunjukkan bahwa variabel thin capitalization berpengaruh positif terhadap tax avoidance. Penelitian ini akan menguji kembali pengaruh thin capitalization terhadap tax avoidance sehingga dirumuskan hipotesis:

$H_{1}$ : Thin capitalization berpengaruh positif terhadap tax avoidance.

Menurut FASB Statement of Concept No.2, konservatisme adalah reaksi hati-hati untuk menghadapi ketidakpastian dan risiko terhadap situasi bisnis telah dipertimbangkan di masa yang akan datang. Konservatisme akuntansi memiliki manfaat atau peranan di dalam teori keagenan yang paling efisien yang bisa membatasi konflik keagenan. Di dalam aktivitasnya seringkali perilaku agen meningkatkan kesejahteraanya sendiri sehingga konservatisme akuntansi dapat mencegah asimetri informasi dengan cara membatasi agen untuk melakukan praktik manipulasi laporan keuangan. Reaksi hati-hati ini berdampak terhadap komitmen manajemen untuk memberi informasi terkait laporan keuangan yang transparan akurat dan tidak menyesatkan adalah faktor yang menentukan tingkat konservatisme akuntansi dalam pelaporan keuangan perusahaan (Hartoto, 2018). Semakin diterapkannya konservatisme akuntansi dalam perusahaan, maka sikap kehati-hatian akan pembuatan laporan keuangan juga akan semakin besar, dan kegiatan tax avoidance akan semakin kecil untuk dilakukan. Hal ini didukung Sjahputra (2019) yang menyatakan bahwa konservatisme akuntansi berpengaruh negatif terhadap tax avoidance. Penelitian ini akan menguji kembali pengaruh konservatisme akuntansi terhadap tax avoidance sehingga dirumuskan hipotesis:

$\mathrm{H}_{2}$ : Konservatisme akuntansi berpengaruh negatif terhadap tax avoidance.

Teori agensi menyatakan bahwa agen akan berusaha mengelola beban pajaknya agar tidak mengurangi kompensasi kinerja agen sebagai akibat dari tergerusnya laba perusahaan oleh beban pajak. Dengan demikian agen akan cenderung melakukan aktivitas penghindaran pajak agresif. Dengan adanya kepemilikan institusional sebagai salah satu elemen corporate governance, maka diharapkan perusahaan akan menyeimbangkan modal dari utang dan 
investasi modal dari pemegang saham dalam struktur modalnya sehingga dirumuskan hipotesis:

$H_{3}$ : Kepemilikan Institusional memperlemah pengaruh thin capitalization terhadap tax avoidance.

Dengan adanya kepemilikan institusional sebagai salah satu elemen corporate governance, maka diharapkan tingkat konservatisme akuntansi perusahaan akan meningkat dan perusahaan cenderung tidak melakukan penghindaran pajak. Hal ini didasarkan pada prinsip-prinsip GCG yang terdiri dari transparansi, akuntabilitas, responsibilitas, independensi, serta kewajaran dan kesetaraan sehingga dirumuskan hipotesis:

$\mathrm{H}_{4}$ : Kepemilikan Institusional memperkuat pengaruh konservatisme akuntansi terhadap tax avoidance.

Adapun model kerangka konseptual penelitian dapat diilustrasikan pada gambar berikut:

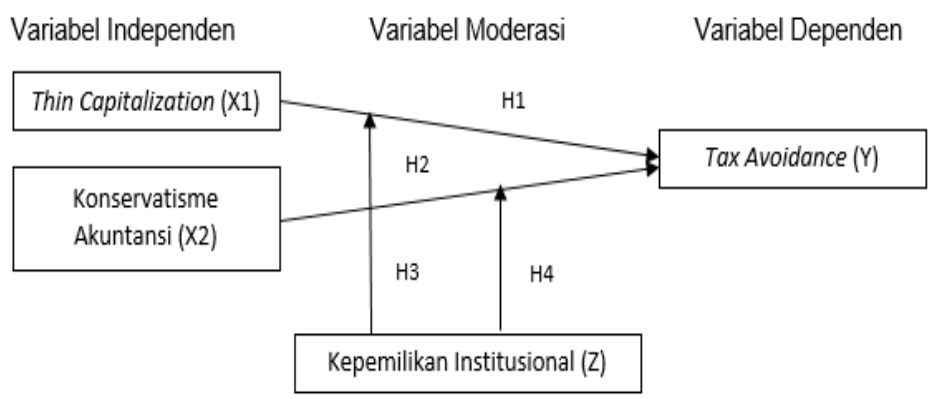

Gambar 1. Kerangka Konseptual

\section{METODE PENELITIAN}

Populasi penelitian ini yaitu perusahaan Manufaktur kategori Consumer Goods Industry yang terdaftar di Bursa Efek Indonesia (BEI) selama periode 2014-2018. Penelitian ini menggunakan metode purposive sampling dengan kriteria sebagai berikut: (1) Perusahaan sudah listing sejak tahun 2014, (2) Perusahaan yang memiliki laporan tahunan yang lengkap, (3) Perusahaan yang melakukan pembayaran Pajak Penghasilan di laporan arus kas, (4) Perusahaan yang tidak melakukan refund atas lebih bayar, (5) Perusahaan tidak mengalami kerugian. Berdasarkan teknik sampling tersebut diperoleh 22 perusahaan yang representatif sebagai sampel. Teknik pengumpulan data dalam penelitian ini adalah menggunakan data sekunder yaitu data laporan tahunan yang diperoleh dari situs BEI dan website perusahaan terkait.

Sampel dalam penelitian ini adalah perusahaan consumer goods yang terdaftar pada Bursa Efek Indonesia pada tahun 2014-2018 dan berada dalam kondisi laba. Teknik analisis menggunakan regresi linier berganda dengan persamaan sebaga berikut :

$$
\begin{gathered}
\text { CETRit }=\beta 0+\beta 1 \text { TCAPit }+\beta 2 \text { KONACCit }+\beta 3 \text { KI }+\beta 4 \text { TCAPit } * \text { KI }+\beta 5 \text { KONACCit } * \text { KI } \\
+\beta 6 A G E+e
\end{gathered}
$$

Definisi operasional variabel dan pengukurannya adalah sebagaimana tabel berikut : 
Pengaruh Thin Capitalization dan Konservatisme Akuntansi ...

Vinka Jumailah

Tabel 1. Definisi Operasional Variabel

\begin{tabular}{|c|c|c|c|}
\hline No & Variabel & Rumus & \\
\hline 1 & Tax Avoidance & (Pembayaran Pjk/Laba Sblm Pjk) x -1 & Rasio \\
\hline 2 & Thin Capitalization & Utang/Modal & Rasio \\
\hline 3 & Konservatisme Akuntansi & $\frac{N I-C F}{R T A} \times(-1)$ & Rasio \\
\hline 4 & Kepemilikan Institusional & $\frac{\text { Jumlah Saham Institusi }}{\text { Jumlah Saham yang Beredar }} \times 100 \%$ & Rasio \\
\hline 5 & Umur Perusahaan & Tahun Penelitian-Tahun IPO Perusahaan & Rasio \\
\hline
\end{tabular}

\section{HASIL DAN PEMBAHASAN}

Analisis deskriptif statistik atas seluruh variabel adalah sebagaimana tabel berikut :

Tabel 2. Statistik Deskriptif

\begin{tabular}{lcrrrl}
\hline & $\mathrm{N}$ & \multicolumn{1}{c}{ Min } & \multicolumn{1}{c}{ Max } & \multicolumn{1}{c}{ Mean } & Std. \\
\hline Y (Tax) & 110 & -0.47 & -0.09 & -0.2729 & .08862 \\
M (KI) & 110 & 0.36 & 0.98 & 0.7342 & .17204 \\
X1 (TCAP) & 110 & 0.16 & 1.32 & 0.6422 & .33374 \\
X2 (KON_ACC) & 110 & -0.07 & 0.12 & 0.1400 & .04631 \\
\hline
\end{tabular}

Sumber: Data diolah, 2019.

Adapun hasil Uji Asumsi Klasik adalah sebagaimana tabel-tabel berikut :

Tabel 3. Hasil Uji Normalitas

\begin{tabular}{ccc}
\hline & Unstandardized Residual & Kesimpulan \\
\hline Asymp. Sig. (2-tailed) & 0.200 & Data terdistribusi normal \\
\hline Sumber: Data diolah, 2019. & &
\end{tabular}

Tabel 4. Hasil Uji Multikolinearitas

\begin{tabular}{ccrl}
\hline \multirow{2}{*}{ Model } & \multicolumn{2}{c}{ Collinearity Statistics } & \multirow{2}{*}{ Kesimpulan } \\
\cline { 2 - 3 } & Tolerance & \multicolumn{1}{c}{ VIF } & Tidak ada multikolinearitas \\
TCI & .945 & 1.058 & Tidak ada multikolinearitas \\
KON_ACC & .510 & 1.962 & Tidak ada multikolinearitas \\
KI_TCAP & .600 & 1.668 & Tidak ada multikolinearitas \\
KI_KA & .400 & 2.502 & Tidak ada \\
AGE & .478 & 2.091 & Tidak ada multikolinearitas \\
\hline
\end{tabular}

Sumber: Data diolah, 2019.

Tabel 5. Hasil Uji Autokorelasi

\begin{tabular}{cc}
\hline DW & Kesimpulan \\
\hline Sumber: Data diolah, 2019.
\end{tabular}


Tabel 6. Hasil Uji Heterokedastisitas

\begin{tabular}{clc}
\hline Model & Sig. & Kesimpulan \\
\hline (Constant) & .169 & Tidak ada heterokedastisitas \\
KI & .774 & Tidak ada heterokedastisitas \\
TCAP & .963 & Tidak ada heterokedastisitas \\
KON_ACC & .977 & Tidak ada heterokedastisitas \\
KI_TCAP & .650 & Tidak ada heterokedastisitas \\
KI_KA & .952 & Tidak ada heterokedastisitas \\
AGE & .087 & Tidak ada heterokedastisitas \\
\hline
\end{tabular}

Sumber: Data diolah, 2019.

Adapun hasil pengujian hipotesis adalah sebagaimana tabel berikut :

Tabel 7. Hasil Uji Koefisien Determinasi

\begin{tabular}{lc}
\hline \multicolumn{1}{c}{ Model Regresi } & Adjusted R Square \\
\hline Model Regresi Berganda & 0.184 \\
\hline Sumber: Data diolah, 2019. &
\end{tabular}

Tabel 8. Hasil Uji F

\begin{tabular}{cccc}
\hline Model Regresi & F & Sig. & Kesimpulan \\
\hline Model Regresi Berganda & 3.412 & 0.006 & Ho Ditolak \\
\hline
\end{tabular}

Sumber: Data diolah, 2019.

Tabel 9. Hasil Uji t

\begin{tabular}{ccccc}
\hline Variabel & $\mathrm{B}$ & $\mathrm{T}$ & Sig. & Kesimpulan \\
\hline X1 (TCAP) & .408 & 3.284 & .000 & H1 Diterima \\
X2 (KON_ACC) & -.055 & -0.037 & .485 & H2 Ditolak \\
X1.M (TCAPXKI) & -.545 & -3.245 & .000 & H3 Diterima \\
X2.M (KON_ACCXKI) & .349 & .171 & .432 & H4 Ditolak \\
\hline
\end{tabular}

Sumber: Data diolah, 2019.

Pada pengujian hipotesis pertama $\left(H_{1}\right)$ diperoleh nilai signifikansi $\mathrm{t}=0.000<0.05$ dan nilai $B_{1}=0,40$ maka $H_{1}$ diterima, sehingga secara statistik terbukti bahwa thin capitalization berpengaruh positif terhadap tax avoidance. Penelitian ini mendukung oleh penelitian Khomsatun (2012) dan Andawiyah (2019) yang menunjukkan bahwa variabel thin capitalization berpengaruh positif terhadap tax avoidance. Hal ini disebabkan semakin tingginya thin capitalization maka semakin tinggi beban bunga yang harus dibayar perusahaan yang tentunya akan menggerus laba perusahaan dan pada akhirnya mengecilkan pajak penghasilan terutang.

Pada pengujian hipotesis kedua $\left(H_{2}\right)$ diperoleh nilai signifikansi $\mathrm{t}=0.485>0.05$ dan nilai $B_{1}=-0,05$ maka $H_{2}$ ditolak, sehingga secara statistik terbukti bahwa konservatisme akuntansi tidak berpengaruh terhadap tax avoidance. Hasil penelitian ini tidak mendukung penelitian Sjahputra (2019) yang menyatakan bahwa konservatisme akuntansi berpengaruh negatif terhadap tax avoidance. Dalam ini dapat disimpulkan bahwa dengan semakin diterapkannya konservatisme akuntansi dalam perusahaan, tidak akan meningkatkan sikap kehati-hatian akan pembuatan laporan keuangan juga akan semakin besar, dan kegiatan tax avoidance akan semakin kecil untuk dilakukan.

Pada pengujian hipotesis ketiga $\left(H_{3}\right)$ diperoleh nilai signifikansi $\mathrm{t}=0.000<0.05$ dan nilai $B_{1}=-0,545$ maka $H_{3}$ diterima, sehingga secara statistik terbukti bahwa kepemilikan 
institusional dapat memperlemah pengaruh thin capitalization terhadap tax avoidance. Hal ini membuktikan bahwa dengan adanya kepemilikan institusional sebagai salah satu elemen corporate governance, maka perusahaan akan menyeimbangkan modal dari utang dan investasi modal dari pemegang saham dalam struktur modalnya.

Pada pengujian hipotesis keempat $\left(H_{4}\right)$ diperoleh nilai signifikansi $\mathrm{t}=0.432>0.05$ dan nilai $B_{1}=0,349$ maka $H_{4}$ ditolak, sehingga secara statistik terbukti bahwa kepemilikan institusional tidak dapat memperkuat pengaruh konservatisme akuntansi terhadap tax avoidance. Dengan adanya kepemilikan institusional sebagai salah satu elemen corporate governance, maka tidak akan meningkatkan konservatisme akuntansi perusahaan dan perusahaan akan tetap melakukan penghindaran pajak tanpa terlalu memperhatikan prinsipprinsip GCG yang terdiri dari transparansi, akuntabilitas, responsibilitas, independensi, serta kewajaran dan kesetaraan.

\section{KESIMPULAN}

Kesimpulan hasil penelitian membuktikan bahwa thin capitalization berpengaruh positif terhadap tax avoidance, konservatisme tidak berpengaruh terhadap tax avoidance, kepemilikan institusional dapat memperlemah pengaruh thin capitalization terhadap tax avoidance, dan kepemilikan institusional tidak dapat memoderasi pengaruh konservatisme akuntansi terhadap tax avoidance.

\section{DAFTAR PUSTAKA}

Andawiyah, A. \& Subekti, A. (2019). Pengaruh Thin Capitalization terhadap Penghindaran Pajak Perusahaan Index Saham Syariah Indonesia. Akuntabilitas: Jurnal Penelitian Dan Pengembangan Akuntansi, 13(1), p.49-68.

Carolina, E. dan Meyliana. (2015). Pengaruh Profitabilitas, Leverage, Ukuran Perusahaan, Ukuran Dewan Komisaris, Kepemilikan Manajerial, dan Kepemilikan Institusional Terhadap Pengungkapan Tanggung Jawab Sosial Perusahaan. Jurnal Akuntansi, 7(2), p.160-177.

Hartoto, R. I. (2018). Pengaruh Financial Distress, Corporate Governance dan Konservatisme Akuntansi terhadap Tax Avoidance (Studi Empiris pada Perusahaan Perbankan yang Listing di BEI tahun 2015-2017). Skripsi. Universitas Islam Indonesia, Yogyakarta.

Khairandy, R. \& Malik, C. (2007). Good Corporate Governance: Perkembangan Pemikiran dan Implementasinya di Indonesia dalam Perspektif Hukum. Yogyakarta: Kreasi Total Media.

Khomsatun dan Martani. (2015). Pengaruh Thin Capitalization dan Asset Mix Perusahaan Indeks Saham Syariah Indonesia (ISSI) terhadap Penghindaran Pajak. Prosiding Simposium Nasional Akuntansi XVIII. 16-19 September 2015, Sumatera utara, Indonesia.

Kurniasih, T. \& Sari M.M.R. (2013). Pengaruh Return on Assets, Leverage, Corporate Governance, Ukuran Perusahaan dan Kompensasi Rugi Fiskal pada Tax Avoidance. Buletin Studi Ekonomi, 18(1), p.58-66.

Mardiasmo. (2003). Perpajakan. Andi, Yogyakarta. 
Olivia, I. \& Dwimulyani, S. (2019). Pengaruh Thin Capitalization dan Profitabilitas terhadap Penghindaran Pajak dengan Kepemilikan Institusional Sebagai Variabel Moderasi. Prosiding Seminar Nasional Pakar Ke 2.

Sarra, H. D. (2017). Pengaruh Konservatisme Akuntansi, Komite Audit dan Dewan Komisaris Independen terhadap Penghindaran Pajak (Studi Empiris Pada Industri Kimia dan Logam di Bursa Efek Indonesia Periode 2010-2014). Competitive, 1(1), p.63-86.

Sjahputra, A. (2019). Determinan Tax Avoidance pada Perusahaan Food and Beverages di Indonesia. Scientific Journal Of Reflection: Economic, Accounting, Management and Business, 2(4), p. 371-380.

Taylor, G. \& Richardson, G. (2013). The Determinants of Thinly Capitalized Tax Avoidance Structures: Evidence from Australian Firms. Journal of International Accounting, Auditing and Taxation, 22, p.12-25.

www.tirto.id / diakses pada 13/11/2019 pukul 20.45

www.online-pajak.com / diakses pada 13/11/2019 pukul 22.00 